\title{
An Analysis of Well-Being in Retirement: \\ The Role of Pensions, Health, and 'Voluntariness' of Retirement
}

\author{
Keith A. Bender \\ University of Wisconsin-Milwaukee
}

\begin{abstract}
This paper examines a wide range of determinants of retiree well-being of retirees. Using data from the 2000 Health and Retirement Study, increases in economic factors such as income lead to higher well-being, although relative income has a larger effect than absolute income. The strongest predictors are the voluntariness of entering retirement, pension characteristics, and health. Retirees "forced" to retire or have defined contribution pensions or bad health have significantly lower well-being. The results suggest a more nuanced approach in addressing retiree well-being than just a focus on the economic well-being of retirees.
\end{abstract}

Keywords: Subjective well-being; employee pension plans; retirement; health

JEL: J14, I31

Forthcoming: Journal of Socio-Economics (2012) 
An Analysis of Well-Being in Retirement:

The Role of Pensions, Health, and 'Voluntariness' of Retirement

\section{Introduction}

Financial or economic well-being in retirement has been of increasing interest for economic researchers. The policy implications are large. As the baby boom generation nears retirement, understanding the determinants of economic well-being enables policy makers to evaluate and possibly reform present retirement institutions, such as public and private pension programs, as well as potentially generate new institutions to meet the demands of the soon to be rapidly increasing retirement population. Of particular interest in this field has been the focus on retirement income adequacy, that is, the financial resources retirees need to be above some minimal level.

While this area of research is important, focusing on just the economic well-being of individuals may miss other factors that influence general well-being. Indeed, there has been relatively little research on other aspects of well-being for retirees in the economics literature. This is a bit surprising given the recent increased interest by labor economists in examining the well-being of workers (i.e. overall job satisfaction or satisfaction with some aspect of the job such as pay, promotion prospects, etc.) and of people in general (Frey and Stutzer 2003a).

This paper, therefore, extends the literature in two ways. First, while there have been several studies of subjective retiree well-being, they tend to be narrowly focused on just a few correlates. This paper using a large group of covariates from the 2000 Health and Retirement Study, in order to compare relative effects of socio-demographic, economic, and noneconomic determinants of well-being. This larger set of determinants come from key findings in the job satisfaction and economics of well-being literatures. In general, the findings are that economic factors such as income and wealth positively impact well-being, although the effects are larger 
for increases in relative income compared to absolute income. Noneconomic factors such as whether retirees chose to retire or not, the health of retirees, and the riskiness of employer pensions, however, had much larger marginal effects on well-being in general, suggesting that the focus by many on the economic well-being of retirees are only looking at part of the story.

A second innovation of this paper is that for the first time in the literature examines whether behavior of retirees changes over time in response to lower levels of well-being. Results here suggest that retirees with low levels of well-being do change their behavior through changing their place of residence or going back to work or changing marital status.

The paper is organized as follows. The next section reviews the economics literature on well-being measures, both in the job and in life. The third section explains the data and methodology used in the research, while the fourth section reviews the results. A final section summarizes the study and offers areas of future research.

\section{Literature Review}

In economics, measures of retiree well-being have primarily focused on two economic measures of well-being. The most common metric is retirement income as summarized in Andrews (1993) and Radner (1998). The other common metric is examining wealth, generally financial assets, net housing value, and the present discounted value of Social Security retirement and pension benefits (see Levine et al. 2000). Regardless of the measure, the research on economic well-being often examines which factors lead to higher levels of retirement income and/or wealth, assuming that this leads to increased overall well-being. Other research, such as Haveman et al. (2003), examines the changes in these measures of economic well-being for retirees as they age. 
However, it is important to realize that economic well-being is only one dimension of overall well-being. Recent surveys by Frey and Stutzer (2002a and 2002b) summarize the mounting research on overall well-being (as measured by happiness or life satisfaction) and their (2002b) research shows the relative importance of nonfinancial and financial variables on the formation of subjective well-being. ${ }^{1}$

While there have been many economics studies on the determinants of life satisfaction (see, for example, the citations in Frey and Stutzer 2002a), only a couple have focused directly on the well-being of retirees. Several papers focus primarily on retirement's influence on life satisfaction or happiness. ${ }^{2}$ First, Wottiez and Theeuwes (1998) examine Dutch data of 43 to 63 year olds and find that those who retired early have higher life satisfaction than workers, although normal aged retirees tend to have equal or lower life satisfaction compared to workers. In a second paper, Charles (2004) finds that retirement among men leads to lower life satisfaction. However, after controlling for endogeneity, he finds that retirement and life satisfaction are positively correlated. Neither study focuses directly on retiree well-being and its determinants but rather they compare the life satisfaction of retired to nonretired individuals. Finally, Calvo et al. (2009) examine the impact of a phased retirement on retiree happiness. ${ }^{3}$

There have been several papers in the literature that directly examine retirement satisfaction. Shultz et al. (1998) examine the retirement satisfaction of early retirees from the

\footnotetext{
${ }^{1}$ Many economists criticize such research as not being tied to economic behavior. However, Blanchflower and Oswald (1999) report that social psychologists have often found that job satisfaction measures correlate with many objective outcomes. For example, Morisha (1986) and Clark et al. (1998) find that workers with lower self-reported job satisfaction have higher absenteeism and higher quit rates. Further, Iaffaldano and Muchinsky (1985) and Ostroff (1992) report that higher job satisfaction within a firm is positively correlated with its performance. As shown below, lower retirement satisfaction also leads to changes in behavior.

${ }^{2}$ Note that this paper and the empirical estimations below make a distinction between 'happiness' and satisfaction. The 'overall well-being' referred to in this paper examines a specific type of well-being, namely satisfaction with retirement (in the same way that job satisfaction relates only the overall well-being gained from work). Obviously many things not related to retirement per se will affect global well-being (often proxied by happiness). Here the distinction is made to focus on retirement specifically regardless of the other factors that might affect the global well-being of the elderly.

${ }^{3}$ A related literature is the effect of unemployment on life satisfaction. See, for example, Clark and Oswald (1994), Theodossiou (1998), Winkelman and Winkelman (1998), and Cole et al. (2009) for details.
} 
first wave of the Health and Retirement Study (HRS) to examine the relative importance of "push" (e.g. poor health) and "pull” (e.g. leisure) factors on retirement satisfaction. For a small sample of 827 early retirees, they find that push factors are more important for those who are involuntarily retired, pull factors tend to be more important for voluntarily retired. Key in their analysis is the focus on the voluntariness of retirement, although their study is limited in scope to early retirees.

Elder and Rudolph (1999) also use the first wave of the HRS to examine the role of financial planning and expectations on the retirement satisfaction of nearly 1,800 retirees. Although they examine a limited number of covariates, they do find a strong positive correlation between retirement planning and eventual retirement satisfaction and a negative correlation between the involuntariness of retirement on retirement satisfaction. Noone et al. (2009) also investigate the impact of financial planning on retirement satisfaction, but use several waves of the HRS to show that even years into retirement, planning for retirement increases retirement satisfaction.

On the other hand, Panis (2004) examines the 2000 wave of the HRS to examine the role of annuities and wealth on both retirement satisfaction and measures of depression. Again, the list of determinants is limited, but Panis finds that annuities from pensions increase retirement satisfaction and reduce the number of depression symptoms, while Social Security reliance (as measured by how much Social Security contributes to total income) has no statistically significant effect on either well-being measure. Panis, however, does not control for other sources of income or wealth or for the voluntariness of retirement.

Finally, Butrica and Schaner (2005) find that what retirees do with their time is an important determinant of well-being in retirement. Using data from the 2002 wave of the HRS, they find that retirees who work or volunteer have higher levels of subjective well-being than 
those who are not similarly engaged. They also find, however, that there are limits to this engagement since well-being declines after 1000 annual hours in work or volunteering activities.

In sum, the literature on the subjective well-being of retirees has tended to focus on particular determinants of well-being whether it be the choice of retirement (e.g. Shultz et al. 1998 or Calvo et al. 2009), financial planning (e.g. Elder and Rudolph 1999 or Noone et al. 2009), income (e.g. Panis 2004), or time use (e.g. Butrica and Schaner 2005). However the goal of this paper is to put these together with a host of other variables suggested in the job satisfaction literature to determine the relative importance of various economic and noneconomic factors that determine subjective well-being in retirement.

\section{Data and Methodology}

\subsection{Health and Retirement Study}

The data for this study come from the year 2000 Health and Retirement Study (HRS), which started in 1992 as a nationally representative sample of the US 51 to 61 year old population. After deleting observations which did not report being fully retired (the criterion for answering questions about retirement well-being) and others with missing values for at least one variable, the resulting dataset has a sample size of 6,246 retirees.

Dependent Variable. The dependent variable comes from the retirement section of the HRS. Namely if a person self reports as being fully retired in 2000 , he or she is asked the following question, "G136. All in all, would you say that your retirement has turned out to be very satisfying, moderately satisfying, or not at all satisfying?" Table 1 contains the tabulation of the answers to this question, along with some frequencies by general demographic characteristics. Over 60 percent of retirees are very satisfied with their retirement, with another third considering their retirement moderately satisfying. Approximately eight percent are not 
satisfied with their retirement. While there is very little difference between genders, white retirees are more likely to be very satisfied with their retirement (63.3 percent compared to 48.7). Satisfaction is found to increase with age as well.

Independent Variables and Expected Effects on Subjective Well-being. The first set of independent variables capture socio-demographic characteristics (descriptive statistics of the independent variables are available from the author). These variables consist of gender, marital status, race, education, and age. Although there are no strong priors regarding the effect of these socio-demographic characteristics on retirement satisfaction, if the process that determines retirement and job satisfaction are similar, women would have higher retirement satisfaction while those with higher educational qualifications would have lower satisfaction. There is no consistent evidence in the job satisfaction literature regarding the relationship between race and Hispanic ethnicity and satisfaction, so their anticipated effect on retirement satisfaction is unknown. Given the U-shaped relationship between job satisfaction and age (Clark and Oswald 1996), we might expect a similar relationship with retirement satisfaction or possibly that they are in the upward sloping portion of the $\mathrm{U}$.

The next set of variables concerns measures of economic well-being: pension, income and wealth information. One subset of variables give averages of pension (plus annuity), Social Security retirement, and earned income, as well as all other household income and net wealth of the household (each divided by 1000). Increases in these income and wealth variables, often used to directly measure economic well-being (see Wiatrowski 1993), are expected to increase subjective well-being. The other variables capture the type of pension a retiree has. ${ }^{4}$ Given that income from and wealth of pensions, are controlled for, it is hypothesized that these variables proxy for the riskiness of pensions. If retirees are risk adverse, then it is likely that those with

\footnotetext{
${ }^{4}$ See Luchak and Gellatly (2002) for a study on pension characteristics and job satisfaction.
} 
defined contribution (DC) pensions might have lower retirement satisfaction than those with the more secure defined benefit (DB) pensions. Of course, having any pension which will give some resources in retirement should increase well-being over those with no pension.

The third set of variables capture other influences on well-being. There are two reasons why the voluntariness of retirement might influence retiree well-being. First, if individuals are forced to retire early, e.g. because of economic or health reasons, they may retire before they are financially or psychologically ready, which could lead to lower well-being compared to those who voluntarily retire. ${ }^{5}$ Second, those who are forced to retire may be actually unemployed. Previous research by Osberg (1993) and Chan and Stevens (2001) shows that nonworking older workers face more constraints reentering the labor market, meaning that some of the retired could be "discouraged workers," that is, people willing to work, but who decide to drop out of the labor force. Given that unemployment decreases life satisfaction as reviewed above, forced retirement would lead to lower retiree well-being.

Other variables such as health should influence the ability to enjoy the additional leisure time that retirement affords, and the sample shows that a large majority of this sample enjoys at least good health. Likewise access to health insurance should increase well-being. If there is complementarity in leisure time between spouses (Maestas 2002), whether the spouse is retired may increase well-being of the respondent. Nearly two-thirds of the sample have a spouse that is either partially or fully retired. The working status of the respondent may also influence wellbeing. The direction of the effect is unclear, however. As the labor force status/life satisfaction research discussed above shows, individuals who work often have higher life satisfaction even after controlling for the extra income from working. On the other hand, if a retiree is forced to work because of a lack of income, there may be a negative effect of work on retirement well-

\footnotetext{
${ }^{5}$ Previous research by Malo and Munoz-Bullon (2008) on forced separations show that the negative effect of a forced separation is persistent and increases over time.
} 
being. In either case, there are relatively few (less than three percent) of the self-reported fully retired who are employed. ${ }^{6}$

\subsection{Methodology}

As alluded to above, there is debate in the economics literature about whether such measures of subjective well-being actually trace out a utility function. However, building on the research of Frey and Stutzer (2003a), the underlying utility function is assumed to have the form:

$$
\mathrm{U}=\mathrm{U}(\mathrm{C}, \mathrm{N})
$$

where $\mathrm{U}$ is the utility from consuming good and services $(\mathrm{C})$ and various noneconomic factors (N) such as leisure, being married, attitudes toward risk, etc. Unfortunately, like other datasets, the HRS does not have direct measures of $\mathrm{U}$ or $\mathrm{C}$. However, $\mathrm{U}$ is assumed to be proxied by retirement satisfaction. In the case of consumption, $\mathrm{C}$ is proxied by economic variables such as income and wealth. Under the most restrictive assumptions, one could assume that the utility function in equation (1) is the same across all samples, although this assumption can be relaxed by allowing the utility functions to vary across different demographic groups (e.g. by gender, race, etc) by estimating separate regressions by these groups.

The estimating equation then becomes a linearization of equation (1) above:

$$
\mathrm{S}_{\mathrm{i}}=\alpha \mathrm{C}_{\mathrm{i}}+\beta \mathrm{N}_{\mathrm{i}}+\varepsilon_{\mathrm{i}}
$$

where for respondent $\mathrm{i}, \mathrm{S}$ is the well-being variable as measured by retirement satisfaction, $\mathrm{C}$ and $\mathrm{N}$ are vectors of economic and noneconomic variables as described above, $\alpha$ and $\beta$ are estimated coefficient vectors, and $\varepsilon$ is a random error term. Given the ordered nature of $S$, an ordered probit estimation procedure is followed (similar results hold using ordered logit regressions).

\footnotetext{
${ }^{6}$ The previous discussion identifies differences in what economists and people in general consider retirement. Economists typically define retirement as a withdrawal from the labor force, while individuals tend to consider it as a separation from a long standing or career job regardless of their present labor force status. Since this is the way that the HRS interprets retirement, I will also use this definition. Most of the regression results below continue to hold if I consider only those who fit the economist's definition and are not currently in the labor force.
} 
In addition to equation (1), two other specifications are estimated. The first alternative is motivated by the job satisfaction literature (e.g. Clark and Oswald 1996) which has found that relative income influences job satisfaction. In the same vein, it may be that relative retirement income will influence retirement satisfaction. In order to control for this, consider the following reformulation of the regression equation (2):

$$
\mathrm{S}_{\mathrm{i}}=\beta_{0}+\beta_{1} \mathrm{X}_{\mathrm{i}}+\beta_{2} \mathrm{I}_{\mathrm{i}}+\varepsilon_{\mathrm{i}}
$$

where for respondent $i, S_{i}$ is retirement satisfaction, $X_{i}$ is the vector of covariates explained above, $\mathrm{I}_{\mathrm{i}}$ is an income measure, the betas are estimated coefficients, and $\varepsilon_{\mathrm{i}}$ is an error term. To determine the importance of relative income, the following regression equation is estimated:

$$
\mathrm{I}_{\mathrm{i}}=\alpha_{0}+\alpha_{1} \mathrm{X}_{\mathrm{i}}+\alpha_{2} \mathrm{Z}_{\mathrm{i}}+\eta_{\mathrm{i}}
$$

where $\mathrm{Z}_{\mathrm{i}}$ is a vector of covariates related to income, ${ }^{7}$ but not well-being, and the alphas are estimated coefficients. From this regression, income is predicted $\left(\hat{\mathrm{I}}_{\mathrm{i}}\right)$ for each respondent and then subtracted from actual income. This difference replaces actual income, $\mathrm{I}_{\mathrm{i}}$, as a covariate in the following job satisfaction equation:

$$
S_{i}=\beta_{0}+\beta_{1} X_{i}+\beta_{2}^{\prime}\left(I_{i}-\hat{I}_{i}\right)+\varepsilon_{i}
$$

As the difference between actual and predicted income becomes greater, subjective well-being should increase (that is, $\beta_{2}^{\prime}>0$ ), since the respondent is receiving income greater than what would be predicted from his/her characteristics. ${ }^{8}$ This methodology is replicated for each retirement income measure - pension, Social Security retirement, earned, and other household income.

A second estimation alternative is motivated by the very specific subsample of the HRS used, namely those who consider themselves fully retired. Because the designation of full

\footnotetext{
${ }^{7}$ In the results presented below, the variables in the $\mathrm{Z}_{\mathrm{i}}$ vector are the number of people in the household and region of birth.

${ }^{8}$ This is admittedly a strong assumption, since there is no information on to whom retirees might compare their income. Lacking this information, I use the methodology from the economics literature on job satisfaction literature.
} 
retirement is a choice by the respondent, these individuals might be different in nonrandom ways from the rest of the population. This sample selection problem could lead to biases in the estimates of the standard ordered probit regressions discussed above. To attempt to correct for this, I collapse the well-being measure into a dummy variable indicating whether or not individuals are very satisfied with their retirement. With this newly defined dependent variable and another variable that indicates whether a person is fully retired or not, the estimation procedure becomes a bivariate probit with sample selection model. ${ }^{9}$

\section{Results}

\subsection{Basic Results}

The coefficients from ordered probit estimation procedures are not easily interpretable. In order to more easily understand what the coefficients mean, they have been transformed into the marginal effects on being in the highest retirement satisfaction category (other marginal effects as well as the untransformed coefficients are available from the author). The first column of Table 2 contains the estimated coefficients of the ordered probit regression for retirement satisfaction. As in the job satisfaction literature (e.g. Clark 1997 and Bender et al. 2005), male retirees have lower retirement satisfaction than female retirees, ceteris paribus, although the marginal effect is small, with males being 3.5 percent less likely of being in the highest retirement satisfaction category. Being married increases the probability of being in the highest category by 6.2 percent. There are no statistically significant effects by race or education, however, which mimics the inconclusive results in the job satisfaction literature. The results show that older retirees have higher retirement satisfaction than those who are under 62 years

\footnotetext{
${ }^{9}$ This method requires including variables that influence the selection equation but do not influence the well-being regressions. In the results presented below, these variables include number of individuals in the household and region of birth (one of the nine US Census regions or born outside of the US).
} 
old, with the marginal effects of the 70 to 74 and $75+$ age groups being 13.5 and 18.0 percent higher for being in the highest satisfaction category compared to those who are under 62 years old. This is consistent with the "right hand" portion of the familiar U-shaped age-satisfaction relationship as found in Clark et al. (1996).

The next set of variables measure any effects of pension characteristics, income sources and net household wealth. As expected income and wealth tend to increase retirement satisfaction. Pension, Social Security, and other household income all increase retirement satisfaction as found in Noone et al. (2009), while there is a U-shaped relationship between satisfaction and wealth - a nonlinear relationship not found previously in the literature. Only extra income from earnings does not increase satisfaction.

The point estimates of the marginal effects imply a relatively small impact of income on retirement satisfaction. In all cases the marginal effects associated with an increase in income by $\$ 1000$ increases the probability of being in the highest satisfaction category by 0.3 percent. On the other hand, it should be noted that these are annual income amounts and a $\$ 1000$ variation may be relatively small in relation to average income. Indeed, the average Social Security and pension+annuity income is $\$ 8,005$ and $\$ 6,758$, respectively, but there are large standard deviation around those averages of $\$ 4877$ and $\$ 14,556$, respectively. If we extrapolate on the basis of these standard deviations, the marginal effect of increasing income from these sources by a standard deviation would increase the probability of being in the highest satisfaction group by 1.5 and 4.4 percentage points respectively. Thus, even by these calculations, the marginal effects are relatively small.

Why might this be the case? It is not immediately clear, but it may be partially explained by the important antipoverty effects of Social Security. If most individuals are lifted out of poverty by Social Security (Grad 1990), they may focus their attention on noneconomic 
measures of well-being. Indeed, if one splits the sample by poverty status, the marginal effect of a $\$ 1000$ increase in total household income is 0.4 percent for those in poverty but only 0.04 percent for those above the poverty level, a ten-fold difference. (Full results are available from the author upon request.) ${ }^{10}$

Even after controlling for pension income, the type of pension plays an important role, as it does in the job satisfaction literature. Having no pension decreases the probability of being in the highest satisfaction category by 7.3 percent compared to those with only DB pensions. Interestingly, having just a DC pension reduces the probability of being in the highest job satisfaction category by 9.8 percent, possibly showing the effects of the relatively high personal risk faced by those with DC plans. This negative effect on retirement satisfaction is seemingly mitigated when DC plans are combined with DB plans since there is no statistically significant difference with those with just DB plans.

Many of the rest of the variables have statistically significant influences on retirement satisfaction. As found previously (Shultz et al. 1998 and Elder and Rudolph 1999), compared to those who voluntarily retired, those who were forced or partially forced to retire had lower retirement satisfaction holding other variables constant. This may reflect that retirement happened before they expected it (Dwyer and Hu 2000). The marginal effects for these variables are relatively large. Those who are forced to retire are 29.7 percent less likely to report being in the highest satisfaction category (nearly half of the 61.6 percent predicted probability of being in that category) while those who were partially forced to retire are 20.1 percent less likely to be in that category. To get a sense of the relative magnitudes of these involuntary retirement variables, using the retirement satisfaction ordered probit coefficient estimates, it would take an increase of more than $\$ 110,000(\$ 73,000)$ of pension income to wipe out the negative effect of

\footnotetext{
${ }^{10}$ Of course, it may be that absolute income matters little while relative income matters a lot as argued by Easterlin (1995). Below I investigate the importance of relative income as a determinant of well-being.
} 
being forced (partially forced) to retire. On the other hand because of the different relative (subjective) value of income, it would take an increase of more than $\$ 574,000(\$ 381,000)$ of other household income to overcome the negative effects of involuntary retirement.

Likewise, having less than excellent health (the excluded category) leads to lower retirement satisfaction (by magnitudes of 20.6 to 42.8 percent for the bottom three health groups), which is expected if health is a complement to leisure time in utility. Even holding earned income constant, working increases retirement satisfaction, although having a spouse working reduces retirement satisfaction, indicating there may be some complementarity in leisure. Interestingly, having nongovernment health insurance or a combination of government and private health insurance increases satisfaction (by 14.5 and 6.7 percent respectively for the highest satisfaction category) compared to those with just government supplied health insurance (e.g. Medicare, Medicaid, etc). There is no statistically significant difference between having these government health insurance sources and no health insurance, a finding that has not been previously investigated in the literature.

\subsection{Estimates by gender and racelethnicity}

The other columns of Table 2 record the results of the ordered probit estimations by gender and white/nonwhite status for retirement satisfaction. Examining retirement satisfaction across genders first, there are few differences between genders. The most obvious differences are that pension characteristics, income and wealth are statistically significant determinants of retirement satisfaction for men but not women. In addition, the fact that their spouse works decreases male retirement satisfaction but not female satisfaction. Conversely, the final two columns contain results for nonwhite and white retirees. The results show that the male, married, 
pension characteristics, income and wealth influences are driven by white retirees. Age, involuntary retirement, and health all have similar influences on retirement satisfaction. ${ }^{11}$

\subsection{Income and well-being}

One of the interesting results from these estimations is that increased income has a positive, but small, impact on well-being. However, it may not be that absolute levels of income are all that important. As mentioned above, earlier research on subjective well-being has found that relative income may be as important as absolute income in determining job satisfaction (see, for example, Ferrer-i-Carbonell, 2005). This kind of analysis has been applied to the job satisfaction and overall well-being/happiness literature, but has not been utilized in retiree satisfaction. Therefore, in this section, I analyze relative income measures to see if comparison, rather than absolute, income influences retiree well-being.

Table 3 contains selected results from four different specifications of the influence of relative earnings on well-being, reporting the marginal effect on the probability of being in the highest respective well-being category. ${ }^{12}$ In the first two specifications, I use a measure of total household income. In Specification 1, a simple difference between actual and predicted total household income is included as a regressor. As Table 3 shows, as actual income increases above predicted income, there is a statistically significant, although small, increase in the probability of being in the highest satisfaction category, although there is no significant impact on the retirement comparison measure. An alternative to including the difference is creating a dummy variable indicating when an individual has greater than predicted income, which is what is done in Specification 2. Both coefficients on this indicator variable are statistically significant

\footnotetext{
${ }^{11}$ Separate regressions were also estimated for those who voluntarily retired or not. Full results are available from the author, but the key difference is for those not voluntarily retired, pension characteristics and net worth are relatively more important, as found in Elder and Rudolph (1999). For the former, the effect is likely due to the inability to accumulate their pension account balances while the latter effect may be due to the relative reliance on other accumulated assets to finance retirement.

${ }^{12}$ First stage income regression results are found in Appendix Table A. The effect of the nonincome covariates on well-being in Table 3 are similar to the previous results in Table 2. Full results are available from the author.
} 
and positive, although the marginal effect on retirement satisfaction is greater than the effect on retirement comparison (a 6.8 percent compared to a 3.5 percent increase).

The next two specifications decompose income into four component parts - pension, Social Security retirement, earned, and other household income. Using the method described above and the regression coefficients found in Appendix Table A, differences between actual and predicted levels of income are included as regressors in Specification $3 .{ }^{13}$ As before, differences in actual and predicted pension, Social Security and other household income are associated with higher retirement satisfaction. A thousand dollar increase in the actual-predicted difference in pension or Social Security income influences the probability more at the margin than a thousand dollar increase in other household income. Replacing the actual difference with an indicator variable, Specification 4, results in similar marginal effects.

\subsection{Controlling for Sample Selection}

The last set of regressions in this section involve controlling for the fact that the sample of the fully retired may be different in nonrandom ways from the rest of the HRS sample. Using the bivariate probit model with sample selection referenced above, I examine if sample selection is influencing the results found above. Table 4 contains the results of this exercise, reporting the marginal effects of the estimated coefficients. ${ }^{14}$

The first and third columns for each well-being measure reports results from a standard probit regression without a selection correction to make sure that the relationships found using the ordered probit are repeated using a probit methodology. By and large, the probit results conform to the results found above. The primary difference is that gender is not important in the

\footnotetext{
${ }^{13}$ For those who are not yet eligible for Social Security retirement benefits, their Social Security income difference is zero. Since this is a relatively large portion of the sample, Specifications 3 and 4 were also estimated for those who are 62 years old or older. The results are not significantly different than those reported in Table 3.

${ }^{14}$ Appendix Table B has the results from the fully retired/not fully retired part of the selection regression.
} 
retirement satisfaction probit. On the other hand, the second column contains the results of the sample selection corrected probits. For retirement satisfaction, the same set of variables continue to be important with similar magnitudes for the marginal effects, indicating that sample selection does not seem to be an important issue for this group. Indeed, the $\chi^{2}$ test for independence shows that we cannot reject independence, indicating a lack of support for sample selection. Seemingly, then, sample selection is not a large problem with this sample.

\section{Do Retirees Change Behavior Because of Low Levels of Well-being?}

The analysis above sheds light on the relative importance of various economic and noneconomic factors that determine subjective well-being in retirees. An interesting side issue is whether retirees change their behavior in any way because of low levels of well-being. Tracking retirees between 2000 and 2002, three such changes are investigated: whether individuals change their residence, whether they get a job (conditional on them not having a job in year 2000), and whether their marital status changes. The dependent variable in each of these probit regressions equals one when a change occurs between years 2000 and 2002.

Selected results are found in Table $5 .^{15}$ In general, high levels of well-being and satisfaction mean a retiree is less likely to make one of these three changes. Being very satisfied with retirement in 2000 reduces the probability of changing one's residence by 4.8 percentage points (compared to a predicted probability of 14.4 percent). On the other hand, differences in well-being do not seem to impact the re-entry into paid employment, ceteris paribus. Perhaps this is because of barriers to work (Osberg 1993 and Chan and Stevens 2001) due to ill health, discrimination, or lack of correct skill sets. If there are barriers, then there may be a queue of

\footnotetext{
15 The other covariates, all measured in the 2000 survey, include, marital status (except in the marital change regression), gender, race/ethnicity, educational status, total household income and its square, total net worth and its square, self assessed health, working status of respondent (except in the re-entering workforce regression), working status of spouse (except in the marital change regression), and region of residence.
} 
retirees wanting paid work, but not being able to attain it. Unfortunately the HRS does not have the information to capture these queues. ${ }^{16}$ Finally, those who are either somewhat or very satisfied are less likely to make a marital change over time compared to those who are not satisfied with retirement. For any voluntary change in marital status (those who become widow(er)s are excluded), there is a reduction of 0.3 and 0.7 percent respectively for these groups, compared to a relatively small predicted change of 0.3 percent. Disaggregating this by type of marital change (either getting married or divorced between 2000 and 2002) shows that there are similar magnitudes of the marginal effects for either the newly married or divorced.

\section{Conclusions}

Understanding the factors that determine well-being of retirees is an important economic and policy topic. Although most previous studies examine only economic well-being, this study examines a broader measure of well-being to examine if other determinants than economic wellbeing measures are important. The results show that while economic well-being (as measured by income and wealth) does increase overall well-being, the effect of income is a nuanced one. On the one hand, the effect of an increase in income on retirement satisfaction is quite small, even for relatively large increases in income, suggesting that since many of the elderly are not at poverty levels, the increased income does not generate significantly increased well-being. However, as is found in other research on subjective well-being, relative income does play a significant role. Retirees seem to value having income above the typical amount, particularly in terms of relative pension income, but also for Social Security income. These show the critical importance of such forms of income to the overall well-being of this demographic group.

\footnotetext{
${ }^{16}$ One potential way to do this would be to examine the re-entry into the labor force (rather than just into paid employment) which would mean looking at those who report being unemployed. However, as mentioned above, there may be substantial numbers of discouraged workers among retirees, and so the sample of those who report unemployment may not be particularly representative.
} 
This said, three other factors stand out as having a more important effect on well-being. The first is the reason for retirement. If individuals say that they voluntarily retired, they express much higher levels of well-being compared to those who did not voluntarily retire. It is likely that if they retired before they had expected to, financial or psychological preparations for retirement may not have been fully completed, leading to lower well-being in retirement. Indeed, the effects of involuntary retirement may actually be greater than reported here since the involuntary retired also have lower levels of pension, Social Security, earned, and other household income which would decrease satisfaction even further. The second major factor is health. Unsurprisingly, those with poor health also experience dramatically lower levels of wellbeing. Although neither of these factors are controllable from a policy point of view, they do indicate areas where more research could be done to help assure higher levels of well-being for retirees. The final interesting factor is, even after controlling for pension income and wealth, retirees still have preferences on the type of pension they have. Those with a defined benefit pension, or both a defined benefit and contribution plan report significantly higher levels of wellbeing than those with no pension or only a defined contribution pension, showing the relative risk averseness of this group.

The relative importance of these well-being determinants indicate areas of importance for public policy makers and areas of further research for economists. Indeed, while this study has been done to offer a general assessment of the factors that determine retiree well-being, further research is certainly warranted. One area of research would be to analyze retirement satisfaction in more dynamic context. For example, does retirement satisfaction change over time and if so, what factors influence those changes? Do retirees who are initially dissatisfied with retirement, learn to accept their retirement and increase their satisfaction? Are there other behavior changes in addition to the ones analyzed here that impact retirement satisfaction? How does declining 
health and the impact of health insurance impact retirement satisfaction? More detailed examination of the three main determinants, voluntariness of retirement, health and pension characteristics would also serve as important extensions to this work. 


\section{References}

Andrews, Emily S. 1993. "Gaps in Retirement Income Adequacy." Pp. 1-31 in The Future of Pensions in the United States, edited by Richard Schmitt. Philadelphia: Pension Research Council and University of Pennsylvania Press.

Bender, Keith A., Susan M. Donohue, and John S. Heywood. 2005. "Job Satisfaction and Gender Segregation," Oxford Economic Papers, 57: 479-96.

Blanchflower, David and Andrew Oswald. 1999. "Well-Being, Insecurity and the Decline of American Job Satisfaction.” Working Paper.

Butrica, Barbara A. and Simone G. Schaner. 2005. "Satisfaction and Engagement in Retirement." Perspectives on Productive Aging 2, Washington, DC: Urban Institute.

Calvo, Esteban, Kelly Haverstick, and Steven A. Sass. 2009. "Gradual Retirement, Sense of Control, and Retirees' Happiness.” Research on Aging 31(1): 112-35.

Chan, Sewin and Ann Huff Stevens. 2001. "Job Loss and Employment Patterns of Older Workers.” Journal of Labor Economics 19(2): 484-521.

Charles, Kerwin K. 2004. "Is Retirement Depressing? Labor Force Inactivity and Psychological Well-being in Later Life." Pp. 269-99 in Research in Labor Economics Vol 23: Accounting for Workers Well-being, edited by Solomon Polachek. London: Elsevier Publishing.

Clark, Andrew E. 1997. “Why Are Women So Happy At Work?” Labour Economics 4: 341-72.

Clark, Andrew E., Y. Georgellis, and P. Sanfey. 1998. "Job Satisfaction, Wage Changes and Quits: Evidence from Germany.” Research in Labor Economics 17: 95-122.

Clark, Andrew E. and Andrew J. Oswald. 1994. "Unhappiness and Unemployment." The Economic Journal 104: 648-59.

-----. 1996. “Satisfaction and Comparison Income.” Journal of Public Economics 61: 359-81.

Clark, Andrew E., Andrew J. Oswald, and Peter Warr. 1996. "Is Job Satisfaction U-shaped in Age?” Journal of Occupational and Organizational Psychology 69: 57-81.

Cole, Kenneth, Anne Daly, and Anita Mak. 2009. "Good for the Soul: The Relationship between Work, Wellbeing and Psychological Capital.” Journal of Socio-Economics, 38(3): 46474.

Dwyer, Debra Sabatini and Jianting Hu. 2000. "Retirement Expectations and Realizations: The Role of Health Shocks and Economic Factors." Pp. 274-87 in Forecasting Retirement Needs and Retirement Wealth, edited by Olivia S. Mitchell, P. Brett Hammond, and Anna M. Rappaport. Philadelphia: University of Pennsylvania Press. 
Easterlin, Richard A. 1995. "Will Raising the Incomes of All increase the Happiness of All." Journal of Economic Behavior and Organization 27(1): 35-47.

Elder, Harold W. and Patricia M. Rudolph. 1999. "Does Retirement Planning Affect the Level of Retirement Satisfaction?” Financial Services Review 8: 117-27.

Ferrer-i-Carbonell, A. 2005. "Income and Well-being: An Empirical Analysis of the Comparison Income Effect." Journal of Public Economics 89: 997-1019.

Frey, Bruno S. and Alois Stutzer. 2002a. Happiness and Economics: How the Economy and Institutions Affect Well-being, Princeton, NJ: Oxford University Press.

-----. 2002b. "What Can Economists Learn from Happiness Research?" Journal of Economic Literature 40(2): 402-35.

Grad, Susan. 1990. "Earnings Replacement Rates of New Retired Workers." Social Security Bulletin 53(10): 2-19.

Haveman, Robert, Karen Holden, Kathryn Wilson, and Barbara Wolfe. 2003. "Social Security, Age of Retirement, and Economic Well-being: Intertemporal and Demographic Patterns among Retired-Worker Beneficiaries.” Demography 40(2): 369-94.

Iaffaldano, Michelle T. and Paul M. Muchinsky. 1985. "Job Satisfaction and Job Performance: A Meta-Analysis.” Psychology Bulletin 97(2): 251-73.

Levine, Philip B., Olivia S. Mitchell, and James F. Moore. 2000. "Women on the Verge of Retirement: Predictors of Retiree Wellbeing." Pp. 167-95 in Forecasting Retirement Needs and Retirement Wealth, edited by Olivia S. Mitchell, P. Brett Hammond, and Anna M. Rappaport. Philadelphia: University of Pennsylvania Press.

Luchak, Andrew A. and Ian R. Gellatly. 2002. "How Pension Accrual Affects Job Satisfaction." Journal of Labor Research 23(1): 145-62.

Maestas, Nicole A. 2002. Planning for Widowhood? Joint Retirement and the Allocation of Pension Income by Older Couples, Dissertation, UC-Berkeley.

Malo, Miguel A. and Fernando Munoz-Bullon. 2008. "Long-term Effects of Involuntary Job Separations on Labour Careers," Journal of Socio-Economics, 37(2): 767-88.

Morisha, Motohiro. 1986. "Job Satisfaction and Desire to Quit: Differences in the Determinants of Two Responses." Pp. 80-91 in Proceedings of the $38^{\text {th }}$ Annual Meeting, Madison, WI: Industrial Relations Research Association.

Noone, Jack H., Christine Stephens, and Fiona M. Alpass. 2009. "Preretirement Planning and Well-Being in Later Life: A Prospective Study.” Research on Aging 31(3): 295-317.

Osberg, Lars. 1993. "Is It Retirement or Unemployment? Induced 'Retirement' and Constrained Labour Supply Among Older Workers" Applied Economics 25: 505-19. 
Ostroff, C. 1992. "The Relationship between Satisfaction, Attitudes and Performance: An Organizational Level Analysis.” Journal of Applied Psychology 77: 963-74.

Panis, Constantijn W. A. 2004. "Annuities and Retirement Well-Being." Pp. 259-74 in Pension Design and Structure: New Lessons from Behavioral Finance, edited by Olivia S. Mitchell and Stephen P. Utkus. Oxford: Oxford University Press.

Radner, Daniel B. 1998. "The Retirement Prospects of the Baby Boom Generation," Social Security Bulletin 61(1): 3-19.

Shultz, Kenneth S., Kelly R. Morton, and Joelle R. Weckerle. 1998. "The Influence of Push and Pull Factors on Voluntary and Involuntary Early Retirees' Retirement Decision and Adjustment." Journal of Vocational Behavior 53: 45-57.

Theodossiou, Ioannis. 1998. "The Effects of Low-pay and Unemployment on Psychological Well-being: A Logistic Approach.” Journal of Health Economics 17: 85-104.

Wiatrowski, William. 1993. "Factors Affecting Retirement Income." Monthly Labor Review 116(3): 25-35.

Winkelman, Liliana and Rainer Winkelman. 1998. "Why Are the Unemployed So Unhappy? Evidence from Panel Data." Economica 65(257): 1-15.

Wottiez, Isolde and Jules Theeuwes. 1998 "Well-being and Labor Market Status." Pp. 211-30 in The Distribution of Welfare and Household Production: International Perspectives, edited by Stephen P. Jenkins, Arie Kapteyn, and Barnard M.S. van Praag. Cambridge: Cambridge University Press. 
Table 1

Percentage Distribution of Satisfaction with Retirement Responses

\begin{tabular}{lccc} 
Sample & Satisfaction with Retirement \\
Moderately Satisfying & Very Satisfying \\
\hline Overall & $7.5 \%$ & $32.4 \%$ & $60.1 \%$ \\
Female & 7.4 & 33.5 & 59.1 \\
Male & 7.6 & 32.3 & 61.2 \\
White & 6.1 & 30.6 & 63.3 \\
Nonwhite & 12.5 & 38.9 & 48.7 \\
Age under 62 (excl) & 14.2 & 33.2 & 52.7 \\
Age 62-64 & 9.0 & 32.6 & 58.5 \\
Age 65-69 & 7.5 & 32.0 & 60.5 \\
Age 70-74 & 6.4 & 30.3 & 63.3 \\
Age 75+ & 5.1 & 33.6 & 61.3 \\
\hline
\end{tabular}


Table 2

Ordered Probit Regression Results by Sample

\begin{tabular}{|c|c|c|c|c|c|}
\hline & Full Sample & Female & Male & Nonwhite & White \\
\hline \multicolumn{6}{|l|}{ Demographic Variables } \\
\hline \multirow[t]{2}{*}{ Male } & $-0.035 * * *$ & & & -0.033 & $-0.037 * *$ \\
\hline & -2.14 & & & -0.95 & -2.00 \\
\hline \multirow[t]{2}{*}{ Married } & $0.062 * * *$ & $0.056^{* *}$ & $0.066^{* * *}$ & 0.016 & $0.070 * * *$ \\
\hline & 3.65 & 2.30 & 2.63 & 0.43 & 3.73 \\
\hline \multirow[t]{2}{*}{ Black } & -0.005 & 0.006 & -0.017 & -0.015 & \\
\hline & -0.23 & 0.22 & -0.48 & -0.35 & \\
\hline \multirow[t]{2}{*}{ Other race } & -0.055 & 0.003 & -0.105 & -0.064 & \\
\hline & -1.15 & 0.04 & -1.74 & -1.07 & \\
\hline \multirow[t]{2}{*}{ Hispanic } & -0.004 & -0.021 & 0.005 & & \\
\hline & -0.13 & -0.44 & 0.11 & & \\
\hline \multirow[t]{2}{*}{ HS degree } & 0.011 & 0.010 & 0.012 & 0.036 & 0.004 \\
\hline & 0.63 & 0.41 & 0.48 & 0.92 & 0.19 \\
\hline \multirow[t]{2}{*}{ Some college } & -0.009 & 0.013 & -0.032 & 0.036 & -0.016 \\
\hline & -0.40 & 0.43 & -1.04 & 0.65 & -0.68 \\
\hline \multirow[t]{2}{*}{ College or postgrad } & 0.014 & 0.042 & -0.013 & -0.040 & 0.016 \\
\hline & 0.54 & 1.15 & -0.37 & -0.70 & 0.58 \\
\hline \multirow[t]{2}{*}{ Age $62-64$} & 0.041 & $0.074 *$ & 0.012 & 0.050 & 0.042 \\
\hline & 1.33 & 1.76 & 0.27 & 0.83 & 1.20 \\
\hline \multirow[t]{2}{*}{ Age $65-69$} & $0.081 * * *$ & $0.086^{* *} *$ & $0.086^{* *}$ & $0.140 * *$ & $0.066^{* *}$ \\
\hline & 2.88 & 2.15 & 2.15 & 2.44 & 2.04 \\
\hline \multirow[t]{2}{*}{ Age $70-74$} & $0.135 * * *$ & $0.166 * * *$ & $0.111 * *$ & $0.195 * * *$ & $0.119 * * *$ \\
\hline & 4.39 & 3.92 & 2.51 & 2.89 & 3.39 \\
\hline \multirow[t]{2}{*}{ Age $75+$} & $0.180 * * *$ & $0.204 * * *$ & $0.163 * * *$ & $0.254 * * *$ & $0.161 * * *$ \\
\hline & 5.80 & 4.74 & 3.61 & 3.89 & 4.52 \\
\hline \multicolumn{6}{|c|}{ Pension Characteristics, Income and Wealth Variables } \\
\hline \multirow[t]{2}{*}{ Pension income/1000 } & $0.003 * * *$ & $0.003 *$ & $0.003 * * *$ & 0.004 & $0.002 * * *$ \\
\hline & 3.09 & 1.77 & 2.62 & 1.57 & 2.77 \\
\hline \multirow[t]{2}{*}{ Soc Sec ret income/1000 } & $0.003 *$ & $1.0 \mathrm{E}-3$ & $0.004^{*}$ & $2.0 \mathrm{E}-5$ & $0.004 * *$ \\
\hline & 1.86 & 0.37 & 1.83 & 0.01 & 2.05 \\
\hline \multirow[t]{2}{*}{ Earnings/1000 } & $-1.1 \mathrm{E}-3$ & $-3.6 \mathrm{E}-4$ & $-1.2 \mathrm{E}-3$ & $1.4 \mathrm{E}-4$ & $-1.4 \mathrm{E}-3$ \\
\hline & -1.36 & -0.20 & -1.43 & 0.10 & -1.56 \\
\hline \multirow[t]{2}{*}{ Other $\mathrm{HH}$ income/1000 } & $5.1 \mathrm{E}-4 * *$ & $4.9 \mathrm{E}-4$ & $5.8 \mathrm{E}-4$ & $6.8 \mathrm{E}-4$ & $4.7 \mathrm{E}-4^{* *}$ \\
\hline & 2.12 & 1.49 & 1.55 & 0.63 & 2.00 \\
\hline \multirow[t]{2}{*}{ Household Net Worth/1000 } & $6.0 \mathrm{E}-5 * * *$ & $6.4 \mathrm{E}-5^{*}$ & $6.4 \mathrm{E}-5^{* *}$ & $1.9 \mathrm{E}-4$ & $5.3 \mathrm{E}-5^{* *}$ \\
\hline & 2.65 & 1.65 & 2.21 & 1.46 & 2.33 \\
\hline \multirow[t]{2}{*}{ Net Worth/1000 Squared } & $-4.4 \mathrm{E}-9 * *$ & $-6.3 \mathrm{E}-9 *$ & $-4.0 \mathrm{E}-9 *$ & $-2.9 \mathrm{E}-8$ & $-3.9 \mathrm{E}-9 * *$ \\
\hline & -2.41 & -1.86 & -1.73 & -1.08 & -2.07 \\
\hline \multirow[t]{2}{*}{ DC pension only } & $-0.098 * * *$ & $-0.081 *$ & $-0.108 * * *$ & 0.041 & $-0.121 * * *$ \\
\hline & -3.14 & -1.67 & -2.74 & 0.67 & -3.52 \\
\hline \multirow[t]{2}{*}{ Both DB and DC pension } & 0.011 & 0.040 & -0.005 & 0.059 & $2.1 \mathrm{E}-4$ \\
\hline & 0.41 & 0.97 & -0.16 & 1.07 & 0.01 \\
\hline \multirow[t]{2}{*}{ Undetermined pension } & -0.059 & -0.027 & -0.075 & 0.092 & -0.101 \\
\hline & -0.89 & -0.22 & -1.00 & 0.58 & -1.50 \\
\hline No pension & $-0.073 * * *$ & -0.047 & $-0.085 * * *$ & 0.012 & $-0.086 * * *$ \\
\hline & -3.18 & -1.33 & -2.75 & 0.24 & -3.43 \\
\hline
\end{tabular}


Table 2 continued

\begin{tabular}{|c|c|c|c|c|c|}
\hline \multicolumn{6}{|l|}{ Other Variables } \\
\hline \multirow[t]{2}{*}{ Forced to retire } & $-0.297 * * *$ & $-0.319 * * *$ & $-0.274 * * *$ & $-0.297 * * *$ & $-0.295 * * *$ \\
\hline & -18.92 & -15.07 & -11.78 & -10.08 & -16.41 \\
\hline \multirow[t]{2}{*}{ Partly wanted, forced ret. } & $-0.201 * * *$ & $-0.239 * * *$ & $-0.163 * * *$ & $-0.165 * * *$ & $-0.209 * * *$ \\
\hline & -8.20 & -7.08 & -4.55 & -3.37 & -7.57 \\
\hline \multirow[t]{2}{*}{ Very good health } & $-0.073 * *$ & $-0.095 * *$ & -0.053 & -0.089 & $-0.070 * *$ \\
\hline & -2.39 & -2.33 & -1.18 & -1.12 & -2.16 \\
\hline \multirow[t]{2}{*}{ Good health } & $-0.206 * * *$ & $-0.224 * * *$ & $-0.192 * * *$ & $-0.133 *$ & $-0.216^{* * *}$ \\
\hline & -7.05 & -5.65 & -4.53 & -1.79 & -6.85 \\
\hline \multirow[t]{2}{*}{ Fair health } & $-0.290 * * *$ & $-0.310 * * *$ & $-0.275 * * *$ & $-0.183 * *$ & $-0.312 * * *$ \\
\hline & -9.59 & -7.67 & -6.14 & -2.51 & -9.40 \\
\hline \multirow[t]{2}{*}{ Poor health } & $-0.428 * * *$ & $-0.450 * * *$ & $-0.411 * * *$ & $-0.355 * * *$ & $-0.436 * * *$ \\
\hline & -14.92 & -12.23 & -9.35 & -5.84 & -13.24 \\
\hline \multirow[t]{2}{*}{ Respondent working } & $0.063 *$ & 0.069 & 0.065 & 0.119 & 0.052 \\
\hline & 1.66 & 1.19 & 1.33 & 1.20 & 1.28 \\
\hline \multirow[t]{2}{*}{ Spouse working } & $-0.055^{* *}$ & -0.054 & $-0.056 * *$ & -0.062 & $-0.046^{*}$ \\
\hline & -2.46 & -1.45 & -2.01 & -1.20 & -1.87 \\
\hline \multirow[t]{2}{*}{ Has other health ins. only } & $0.145^{* * *}$ & $0.139 * * *$ & $0.157 * * *$ & $0.224 * * *$ & $0.126 * * *$ \\
\hline & 5.14 & 3.40 & 4.07 & 3.22 & 4.10 \\
\hline \multirow[t]{2}{*}{ Has both govt and other health ins. } & $0.067 * * *$ & $0.069 * * *$ & $0.065 * * *$ & 0.051 & $0.071 * * *$ \\
\hline & 4.15 & 3.03 & 2.80 & 1.23 & 3.99 \\
\hline \multirow[t]{2}{*}{ No health insurance } & 0.023 & 0.041 & 0.012 & 0.094 & -0.003 \\
\hline & 0.48 & 0.71 & 0.18 & 1.29 & -0.05 \\
\hline Predicted Probability & 0.616 & 0.603 & 0.629 & 0.467 & 0.644 \\
\hline Chi-Squared & $1291.91 * * *$ & $715.18 * * *$ & $645.73 * * *$ & $249.96 * * *$ & $1014.10 * * *$ \\
\hline \# of Observations & 6246 & 3109 & 3137 & 1369 & 4877 \\
\hline
\end{tabular}

Note: Figures are marginal effects, showing the change in probability of being in the highest retirement satisfaction category when an independent variable changes (holding all other variables at their means). 'Predicted Probability' is the probability of being in the highest satisfaction category with all variables at their means. Regressions include eight regional variables and two estimated cut points and use Wave 2000 sample weights. Numbers under coefficient estimates are asymptotic Z-statistics.

* Indicate a significant improvement in the log-likelihood at the $10 \%$ level.

** Indicate a significant improvement in the log-likelihood at the 5\% level.

*** Indicate a significant improvement in the log-likelihood at the $1 \%$ level. 
Table 3

Selected Results from Different Well-being Specifications using Comparison Income

Retirement Satisfaction

Specification 1

Difference in total $\mathrm{HH}$ income

$9.3 \mathrm{E}-4 * * *$

Specification 2

Dummy $=1$ if difference $>0 \quad 0.068 * * *$

Specification 3

Difference in pension income $\quad 0.003 * * *$

Difference in Soc Sec ret. income

(1.97)

Difference in earned income $\quad-4.5 \mathrm{E}-4$

Difference in other $\mathrm{HH}$ income $\quad 8.5 \mathrm{E}-4 * * *$

Specification 4

Dummy $=1$ if pension difference $>0 \quad 0.068 * * *$

(4.38)

Dummy $=1$ if Soc Sec difference $>0 \quad 0.027 *$

(1.89)

Dummy $=1$ if earned difference $>0 \quad-0.021$

Dummy $=1$ if other HH difference $>0 \quad 0.042 * * *$

(2.71)

Notes: Numbers above are marginal effects of a change in the probability of being in the top satisfaction or comparison category. Other covariates in each of the four specifications include all nonincome variables in Table 3. Numbers under coefficient estimates are asymptotic Z statistics. Regressions weighted by Wave 2000 sample weights. Results for the income regressions are given in Appendix Table 1.

* Indicate a significant improvement in the log-likelihood at the $10 \%$ level.

** Indicate a significant improvement in the log-likelihood at the 5\% level.

*** Indicate a significant improvement in the log-likelihood at the $1 \%$ level. 
Table 4

Probit and Sample Selection Results of Retirement Satisfaction

\begin{tabular}{|c|c|c|c|c|c|}
\hline & Probit & $\begin{array}{l}\text { Sample } \\
\text { Selection }\end{array}$ & & Probit & $\begin{array}{l}\text { Sample } \\
\text { Selection }\end{array}$ \\
\hline Demographic Variables & $(1)$ & (2) & Other Variables & $(3)$ & (4) \\
\hline \multirow[t]{2}{*}{ Male } & -0.022 & -0.012 & Forced to retire & $-0.300 * * *$ & $-0.292 * * *$ \\
\hline & -1.22 & -0.40 & & -16.28 & -14.39 \\
\hline \multirow[t]{2}{*}{ Married } & $0.062 * * *$ & $0.071 * * *$ & Partly forced to ret. & $-0.192 * * *$ & $-0.194 * * *$ \\
\hline & 3.32 & 3.47 & & -6.97 & -7.15 \\
\hline \multirow[t]{2}{*}{ Black } & 0.006 & 0.003 & Very good health & $-0.104 * * *$ & $-0.099 * * *$ \\
\hline & 0.25 & 0.12 & & -3.40 & -3.34 \\
\hline \multirow[t]{2}{*}{ Other race } & -0.101 & -0.084 & Good health & $-0.246^{* * *}$ & $-0.242 * * *$ \\
\hline & -1.50 & -1.48 & & -8.23 & -7.88 \\
\hline \multirow[t]{2}{*}{ Hispanic } & 0.065 & 0.022 & Fair health & $-0.337 * * *$ & $-0.328 * * *$ \\
\hline & 1.37 & 0.65 & & -10.60 & -10.23 \\
\hline \multirow[t]{2}{*}{ HS degree } & 0.003 & 0.006 & Poor health & $-0.417 * * *$ & $-0.421 * * *$ \\
\hline & 0.15 & 0.29 & & -11.31 & -12.34 \\
\hline \multirow[t]{2}{*}{ Some college } & -0.002 & $-9.4 \mathrm{E}-4$ & Resp. working & 0.068 & 0.062 \\
\hline & -0.09 & -0.04 & & 1.65 & 1.07 \\
\hline \multirow[t]{2}{*}{ College or postgrad } & 0.022 & 0.031 & Spouse working & $-0.056 * *$ & $-0.062 * *$ \\
\hline & 0.82 & 1.03 & & -2.29 & -2.07 \\
\hline \multirow[t]{2}{*}{ Age 62-64 } & 0.012 & 0.010 & Other health ins. only & $0.165 * * *$ & $0.166^{* * *}$ \\
\hline & 0.34 & 0.28 & & 4.92 & 4.89 \\
\hline \multirow[t]{2}{*}{ Age 65-69 } & $0.085 * *$ & $0.079 * *$ & Govt \& other ins. & $0.076 * * *$ & $0.074 * * *$ \\
\hline & 2.49 & 2.20 & & 4.12 & 4.21 \\
\hline \multirow[t]{2}{*}{ Age70-74 } & $0.128 * * *$ & $0.131 * * *$ & No health ins. & $0.091 *$ & 0.074 \\
\hline & 3.40 & 3.54 & & 1.71 & 1.52 \\
\hline \multirow[t]{2}{*}{ Age $75+$} & $0.157 * * *$ & $0.158 * * *$ & & & \\
\hline & 4.12 & 4.57 & & & \\
\hline \multicolumn{6}{|c|}{ Pension Characteristic, Income and Wealth Variables } \\
\hline \multirow[t]{2}{*}{ DC pension only } & $-0.075^{* *}$ & $-0.084 * *$ & Soc Sec income/1000 & 0.002 & 0.004 \\
\hline & -2.25 & -2.56 & & 1.04 & 1.21 \\
\hline \multirow[t]{2}{*}{ Both DB and DC pension } & 0.014 & 0.013 & Earnings/1000 & $-1.2 \mathrm{E}-3$ & $-1.3 \mathrm{E}-03$ \\
\hline & 0.48 & 0.49 & & -1.51 & -1.44 \\
\hline \multirow[t]{2}{*}{ Undetermined pension } & -0.071 & -0.066 & $\mathrm{HH}$ income/1000 & $6.5 \mathrm{E}-4 * *$ & $5.0 \mathrm{E}-04 *$ \\
\hline & -0.98 & -0.98 & & 2.22 & 1.88 \\
\hline \multirow[t]{2}{*}{ No pension } & $-0.048 *$ & $-0.054 * *$ & HH Net Worth/1000 & $5.6 \mathrm{E}-5 * *$ & $6.4 \mathrm{E}-05 * *$ \\
\hline & -1.85 & -2.17 & & 2.44 & 2.59 \\
\hline \multirow[t]{2}{*}{ Pension income/1000 } & $0.003 * * *$ & $0.003^{*}$ & Net Worth Squared & $-4.1 E-9 * *$ & $-5.0 \mathrm{E}-09 * * *$ \\
\hline & 2.88 & 1.91 & & -2.05 & -2.88 \\
\hline$\chi^{2}$ statistic & $1127.21 * * *$ & $1078.11 * * *$ & & & \\
\hline \# of observations & 6246 & 16,782 & & & \\
\hline $\begin{array}{l}\chi^{2} \text { test for independence } \\
\text { (selection) }\end{array}$ & & 0.18 & & & \\
\hline
\end{tabular}

Regressions include eight regional variables and a constant term. Coefficients are marginal effects. Numbers under coefficient estimates are asymptotic Z statistics. Estimates are weighted by Wave 2000 sample weights. Results for the fully retired sample selection regressions are given in Appendix Table 2.

* Indicate a significant improvement in the log-likelihood at the $10 \%$ level.

** Indicate a significant improvement in the log-likelihood at the 5\% level.

*** Indicate a significant improvement in the log-likelihood at the $1 \%$ level. 
Table 5

Selected Results of Well-being Affecting Behavior

\begin{tabular}{|c|c|c|c|}
\hline Dependent Variable & Somewhat Satisfied & Very Satisfied & Predicted Probability \\
\hline \multirow[t]{2}{*}{ Change in Residence } & -0.026 & $-0.048 * *$ & 0.144 \\
\hline & -1.17 & -2.14 & \\
\hline \multirow[t]{2}{*}{ Working in 2002} & $-7.4 \mathrm{E}-4$ & $-6.9 \mathrm{E}-4$ & 0.020 \\
\hline & -0.07 & -0.06 & \\
\hline \multirow[t]{2}{*}{ Any Marital Status Change } & $-0.003 * *$ & $-0.007 * * *$ & 0.003 \\
\hline & -2.87 & -2.87 & \\
\hline \multirow[t]{2}{*}{ Got Married } & $-0.002 * *$ & $-0.003 * *$ & 0.007 \\
\hline & -2.56 & -2.01 & \\
\hline \multirow[t]{2}{*}{ Got Divorced } & $-3.8 \mathrm{E}-4$ & $-0.002 * *$ & 0.004 \\
\hline & -0.73 & -2.10 & \\
\hline
\end{tabular}

Each row is a different probit regression where the indicated variable shows a change in status between 2000 and 2002. Coefficients are marginal effects. Numbers under coefficient estimates are asymptotic Z statistics. Estimates are weighted by Wave 2000 sample weights.

* Indicate a significant improvement in the log-likelihood at the $10 \%$ level.

** Indicate a significant improvement in the log-likelihood at the 5\% level.

*** Indicate a significant improvement in the log-likelihood at the $1 \%$ level. 
Appendix Table A

Income Ordinary Least Squares Regressions for Comparison Income Regressions

\begin{tabular}{|c|c|c|c|c|c|}
\hline & $\begin{array}{l}\text { Total from } \\
\text { Household }\end{array}$ & $\begin{array}{l}\text { Pension } \\
\text { Income }\end{array}$ & $\begin{array}{c}\text { Social } \\
\text { Security }\end{array}$ & $\begin{array}{l}\text { Earned } \\
\text { Income }\end{array}$ & $\begin{array}{c}\text { Other } \\
\text { Household }\end{array}$ \\
\hline \multirow[t]{2}{*}{ Male } & -0.227 & $3.684 * * *$ & $2.723 * * *$ & $12.792 * * *$ & $-14.008 * * *$ \\
\hline & -0.17 & 17.80 & 30.58 & 11.88 & -11.36 \\
\hline \multirow[t]{2}{*}{ Married } & $17.769 * * *$ & -0.302 & $-1.388 * * *$ & $-3.712 * *$ & $21.112 * * *$ \\
\hline & 15.08 & -1.32 & -14.68 & -2.53 & 22.36 \\
\hline \multirow[t]{2}{*}{ Black } & $-7.963 * * *$ & -0.081 & $-1.288 * * *$ & $-3.631 * * *$ & $-7.832 * * *$ \\
\hline & -6.94 & -0.41 & -9.89 & -3.97 & -7.82 \\
\hline \multirow[t]{2}{*}{ Other race } & $-9.690 * *$ & $-1.505 * * *$ & $-1.991 * * *$ & -2.291 & $-6.884 * *$ \\
\hline & -2.32 & -3.80 & -6.49 & -0.85 & -2.17 \\
\hline \multirow[t]{2}{*}{ Hispanic } & $-10.588 * * *$ & -0.427 & $-2.042 * * *$ & -1.686 & $-7.620 * * *$ \\
\hline & -7.06 & -1.60 & -12.01 & -0.64 & -4.63 \\
\hline \multirow[t]{2}{*}{ HS degree } & $7.559 * * *$ & $1.898 * * *$ & $0.710 * * *$ & 0.675 & $3.409 * * *$ \\
\hline & 7.04 & 13.04 & 7.32 & 1.15 & 4.43 \\
\hline \multirow[t]{2}{*}{ Some college } & $16.110 * * *$ & $3.272 * * *$ & $0.903 * * *$ & $4.126^{* * *}$ & $12.308 * * *$ \\
\hline & 11.03 & 10.49 & 7.39 & 4.45 & 10.13 \\
\hline \multirow[t]{2}{*}{ College or postgrad } & $40.392 * * *$ & $6.779 * * *$ & $1.015 * * *$ & $22.396 * * *$ & $31.503 * * *$ \\
\hline & 16.43 & 18.32 & 7.00 & 10.49 & 13.86 \\
\hline \multirow[t]{2}{*}{ Age 62-64 } & 1.549 & $1.213 * * *$ & & $-3.097 *$ & -1.495 \\
\hline & 0.37 & 3.98 & & -1.71 & -0.65 \\
\hline \multirow[t]{2}{*}{ Age $65-69$} & $-4.178 * *$ & $2.064 * * *$ & $3.316^{* * *}$ & $-11.724 * * *$ & $-3.889 * *$ \\
\hline & -1.72 & 6.74 & 22.30 & -9.15 & -2.28 \\
\hline \multirow[t]{2}{*}{ Age70-74 } & $-7.272 * * *$ & $1.722 * * *$ & $4.181 * * *$ & $-11.731 * * *$ & $-6.114 * * *$ \\
\hline & -3.05 & 5.40 & 27.68 & -5.34 & -3.14 \\
\hline \multirow[t]{2}{*}{ Age $75+$} & $-8.271 * * *$ & $0.911^{* * *}$ & $4.133^{* * *}$ & $-12.458 * * *$ & $-6.104 * * *$ \\
\hline & -3.67 & 2.77 & 28.27 & -8.52 & -3.72 \\
\hline \multirow[t]{2}{*}{ Respondent working } & -1.451 & $-3.407 * * *$ & $-0.109 * *$ & $28.955 * * *$ & $-4.903 * *$ \\
\hline & -0.57 & -14.59 & -2.45 & 24.52 & -2.56 \\
\hline \multirow[t]{2}{*}{ Spouse working } & $20.493 * * *$ & $-0.876^{* * *}$ & $-0.845 * * *$ & 0.403 & $24.730 * * *$ \\
\hline & 7.56 & -3.37 & -7.06 & 0.30 & 14.41 \\
\hline \multirow[t]{2}{*}{ Number of $\mathrm{HH}$ residents } & $-2.184 * * *$ & $-0.302 * * *$ & $-0.371 * * *$ & -0.282 & $-2.636 * * *$ \\
\hline & -4.41 & -4.53 & -2.88 & -0.65 & -6.22 \\
\hline \multirow[t]{2}{*}{ Constant } & $20.755 * * *$ & 1.455 & $4.038 * * *$ & $8.374 * * *$ & $19.706^{* * *}$ \\
\hline & 7.64 & 1.50 & 15.63 & 3.07 & 5.19 \\
\hline $\mathrm{R}$ squared & 0.20 & 0.08 & 0.23 & 0.16 & 0.15 \\
\hline
\end{tabular}

Also included, but not reported, are eight regional indicators. The dependent variable is the log of annual income. Numbers under coefficient estimates are t-statistics. Estimates are weighted by Wave 2000 sample weights.

* Indicate a significant improvement in the log-likelihood at the $10 \%$ level.

** Indicate a significant improvement in the log-likelihood at the 5\% level.

*** Indicate a significant improvement in the log-likelihood at the $1 \%$ level. 


\section{Appendix Table B}

Sample Selection Regression Results for Whether an HRS Respondent Indicates Being 'Fully Retired'

\begin{tabular}{|c|c|c|c|}
\hline Variable & Coefficient & Variable & Coefficient \\
\hline Male & $\begin{array}{l}0.521 * * * \\
17.95\end{array}$ & Net Worth/1000 Squared & $\begin{array}{l}-4.4 \mathrm{E}-9 \\
-1.30\end{array}$ \\
\hline Married & $\begin{array}{l}0.070^{* *} \\
2.40\end{array}$ & Very good health & $\begin{array}{l}0.018 \\
0.40\end{array}$ \\
\hline Black & $\begin{array}{l}0.124 * * * \\
2.98\end{array}$ & Good health & $\begin{array}{l}-0.069 \\
-1.51\end{array}$ \\
\hline Other race & $\begin{array}{l}0.066 \\
0.74\end{array}$ & Fair health & $\begin{array}{l}-0.061 \\
-1.28\end{array}$ \\
\hline Hispanic & $\begin{array}{l}-0.184 * * * \\
-2.79\end{array}$ & Poor health & $\begin{array}{l}-0.162 * * * \\
-2.96\end{array}$ \\
\hline HS degree & $\begin{array}{l}0.127 * * * \\
4.11\end{array}$ & Respondent working & $\begin{array}{l}-1.851 * * * \\
-35.16\end{array}$ \\
\hline Some college & $\begin{array}{l}0.231 * * * \\
6.05\end{array}$ & Spouse working & $\begin{array}{l}-0.240 * * * \\
-6.46\end{array}$ \\
\hline College or postgrad & $\begin{array}{l}0.273^{* * * *} \\
6.10\end{array}$ & Born in mid Atl region & $\begin{array}{l}-0.006 \\
-0.08\end{array}$ \\
\hline Age 62-64 & $\begin{array}{l}0.249 * * * \\
4.63\end{array}$ & Born in ENC region & $\begin{array}{l}-0.082 \\
-1.01\end{array}$ \\
\hline Age 65-69 & $\begin{array}{l}0.463 * * * \\
9.55\end{array}$ & Born in $\mathrm{WNC}$ region & $\begin{array}{l}0.031 \\
0.34\end{array}$ \\
\hline Age70-74 & $\begin{array}{l}0.399 * * * \\
7.49\end{array}$ & Born in South Atl region & $\begin{array}{l}-0.148^{*} \\
-1.82\end{array}$ \\
\hline Age $75+$ & $\begin{array}{l}0.181 * * * \\
3.67\end{array}$ & Born in ESC region & $\begin{array}{l}0.160^{*} \\
1.78\end{array}$ \\
\hline Pension income/1000 & $\begin{array}{l}0.012 * * * \\
5.83\end{array}$ & Born in WSC region & $\begin{array}{l}-0.015 \\
-0.17\end{array}$ \\
\hline Soc Sec ret income/1000 & $\begin{array}{l}0.040^{* * * *} \\
13.13\end{array}$ & Born in Mountain region & $\begin{array}{l}0.188^{*} \\
1.69\end{array}$ \\
\hline Earnings/1000 & $\begin{array}{l}-0.011 * * * \\
-7.70\end{array}$ & Born in Pacific region & $\begin{array}{l}-0.021 \\
-0.21\end{array}$ \\
\hline Other HH income/1000 & $\begin{array}{l}-1.2 \mathrm{E}-3 * * * \\
-2.77\end{array}$ & Born outside US & $\begin{array}{l}-0.051 \\
-0.55\end{array}$ \\
\hline HH Net Worth/1000 & $\begin{array}{l}6.8 \mathrm{E}-5 * \\
1.69\end{array}$ & & \\
\hline
\end{tabular}

Results from a maximum likelihood estimation of a bivariate probit model with sample selection. Numbers under coefficient estimates are asymptotic $\mathrm{Z}$ statistics. Results for the retirement well-being regressions are given in Table 4.

* Indicate a significant improvement in the log-likelihood at the $10 \%$ level.

** Indicate a significant improvement in the log-likelihood at the $5 \%$ level.

*** Indicate a significant improvement in the log-likelihood at the $1 \%$ level. 